\title{
Mangrove Biophysical Condition and Community's Socio-economic Profile as Managers of Mangrove Forest in Tagpait, Aborlan and Bacungan Puerto Princesa City, Palawan, Philippines
}

\author{
Mark Joseph J. Buncag, Ph.D \\ Faculty, Palawan State University, Palawan, Philippines
}

\begin{abstract}
The mangrove forest in Tagpait, Aborlan, is being managed by the Indigenous Cultural Community (Tagbanua Tribe) through their organization, the Tagpait Coastal Development Association (TACDA). Bacungan Mangrove Eco-tourism Service Cooperative is managing the Bacungan mangrove forest. The area was engaged in tourism activity until now through paddle boating, floating restaurant, mangrove adventure. This study used the household interview to determine the socio-economic profile and quadrat to assess mangrove biophysical condition. Results show that Bacungan is more diverse, with a higher number of species present in the area with 13 mangrove species while eight in Tagpait. The most dominant mangrove species in Tagpait is Rhizophora apiculata (39\%), while Rhizophora mucronata in Bacungan (22\%). Most of the respondents in Tagpait are fishers, which about $20 \%$, then $14 \%$ are involved in buy and sell of marine products, and $5 \%$ are engaged in the processing of marine products. In Bacungan, the majority are engaged in fishing livelihood (37\%), 13\% are involved in buy and sell of marine products, and $4 \%$ are engaged in the processing of marine products.
\end{abstract}

Keywords: Mangrove Forest, Mangrove Species and Fishing Livelihood

\section{Introduction}

Community-Based Mangrove Forest Management (CBFM) is an essential instrument to attain sustainability in the management of natural resources like mangrove forests (Datta et al., 2012) (Pokharel et al., 2014). It is highly recommended by both academia and governing agency as a sustainable approach for managing the mangrove forest (Datta et al., 2012).

The mangrove forest in Tagpait, Aborlan, is being managed by the Indigenous Cultural Community (Tagbanua Tribe) through their organization, the Tagpait Coastal Development Association (TACDA). Since the mangrove area is not part of the mangrove reserve of Palawan, cutting for housing lumber needs as well as the aquaculture (shrimps, crabs, and fishes) are allowed by their organization (Regoniel and Pacañot 2012). Aquaculture activities are destroyed during the storm, and the health of the mangroves are also affected. Also, the cutting of mangroves by people from other places or adjacent barangays is a significant problem in the area. This mangrove forest is also engaged in tourism activities like mangrove trekking to increase the income of the local people, aside from fishing and gleaning (Dela Peña et al., 2013).

Bacungan Mangrove Eco-tourism Service Cooperative is managing the Bacungan mangrove forest. The area was engaged in tourism activity until now through paddle boating, floating restaurant, mangrove adventure, etc. Tourism Activity can cause of degradation of the natural resources without sustainable strategies (Khanom et al., 2011). The residents are engaged in aquaculture as the livelihood that caused them to cut trees. Based on Rahman et al. (2010), aquaculture can cause degradation of mangrove forests. This study aims to assess the biophysical condition and socio-economic profile of communities in Tagpait, Aborlan and Bacungan, Puerto Princesa City, Palawan. 


\section{MATERIALS AND METHODS}

This study was conducted in the Barangay Tagpait, municipality of Aborlan $\left(9^{\circ} 24^{\prime} 50.665^{\prime \prime} \mathrm{N}\right.$ and $118^{\circ} 33^{\prime} 20.984^{\prime \prime E}$ ) which is $60 \mathrm{~km}$ away from Puerto Princesa City with 78-hectare of mangrove forest and Barangay Bacungan, Puerto Princesa City, Palawan (9 $53^{\prime} 48^{\prime \prime}$ N and 188 $43^{\prime} 27^{\prime}$ ' E) with 378-hectare of mangrove forest.

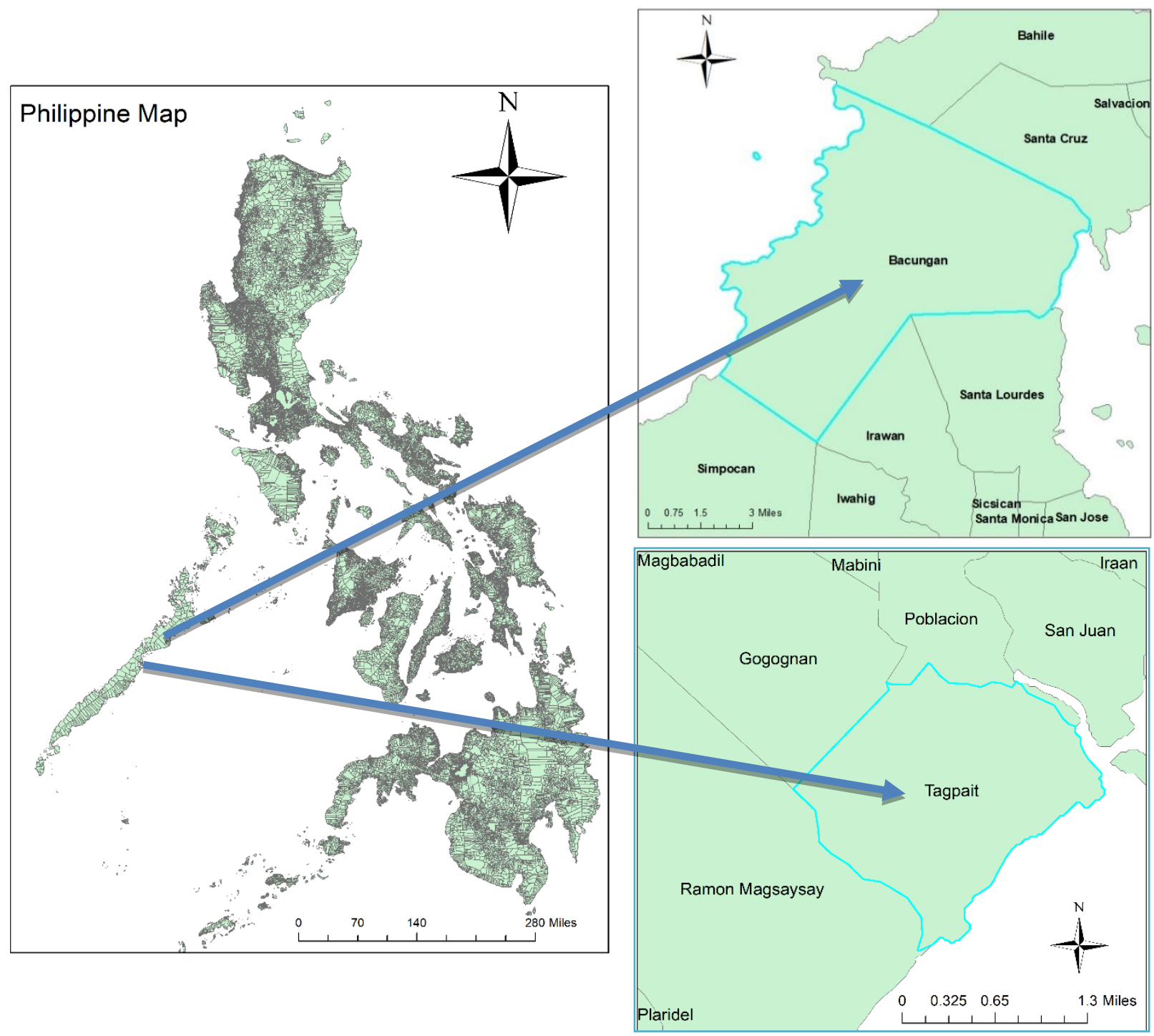

Figure 1. Research Areas: Bacungan, Puerto Princesa City and Tagpait, Aborlan, Palawan

The mangrove in Tagpait and Bacungan were planted mostly with trees of the genus Rhizophora (local name: Bakauan). Most mangrove trees in Bacungan can be found along the river connecting to the east coast of Puerto Princesa City while the mangrove in Tagpait is mostly right after the seashore. Crabs, fishes, shells, and shrimps are the usual resources that can be found in both mangrove areas.

The mangrove forests were assessed in terms of species present, population by species (seedlings, saplings, and mature trees), population density, and diameter breast height using five $(10 \mathrm{~m} \times 10 \mathrm{~m})$ quadrats for each area (PCRA, 2013). 


\section{DOI: $10.51386 / 25815946 / i j s m s-v 4 i 4 p 103$}

Volume: 4 Issue: 4

July to August 2021

https://www.ijsmsjournal.org

Household interview through structured survey questionnaire was utilized to determine the socio-economic profile. The total number of respondents for Household Interview (HHI) was based on Robert Slovin's formula in which the margin of error is 0.05 or $95 \%$ confidence level. The household population of officers and members of peoples' organization (PO) in Tagpait Coastal Development Association (TACDA) in Tagpait, Aborlan, is 78 while 33 in Bacungan Mangrove Eco-tourism Service Cooperative of Bacungan, Puerto Princesa. The computed sample size for Tagpait, Aborlan, and Bacungan, Puerto Princesa, are 65 and 30, respectively. To analyzed the socio-economic characteristics of the respondents and biophysical conditions, descriptive statistics were used. In mangrove soil, laboratory analysis was conducted at the Palawan Soil Analysis Center.

\section{RESULTS AND DISCUSSION}

\section{A. Biophysical Condition}

1. Tagpait

Tagpait, Aborlan has 78-hectare of mangrove composed of eight species, as presented in Figure 2. Mangrove species composition and relative abundance were assessed using four transects with a total of 16 quadrats. The area was planted mostly with trees of the genus Rhizophora. The average height of trees is 19 meters, and the average diameter at breast height $(\mathrm{DBH})$ is four inches $(10.2 \mathrm{~cm})$. The $\mathrm{pH}$ level of soil in Tagpait is 7.16, which indicates almost neutral. Nitrogen $(\mathrm{N})$, Phosphorus $(\mathrm{P})$, and Potassium $(\mathrm{K})$ is $1.5 \% \mathrm{OM}, 190 \mathrm{ppm}$, and 256ppm, respectively. The percentage of soil organic carbon stock for $100 \mathrm{~g}$ is $0.6 \%$ (0.6 grams), while the percentage of organic matter is $1.032 \%(1.032 \mathrm{~g})$. Carbon Seqestration is one of the benefits provided by the forest to lessen emission of carbon dioxide in the atmosphere (Lasco et al., 2006).

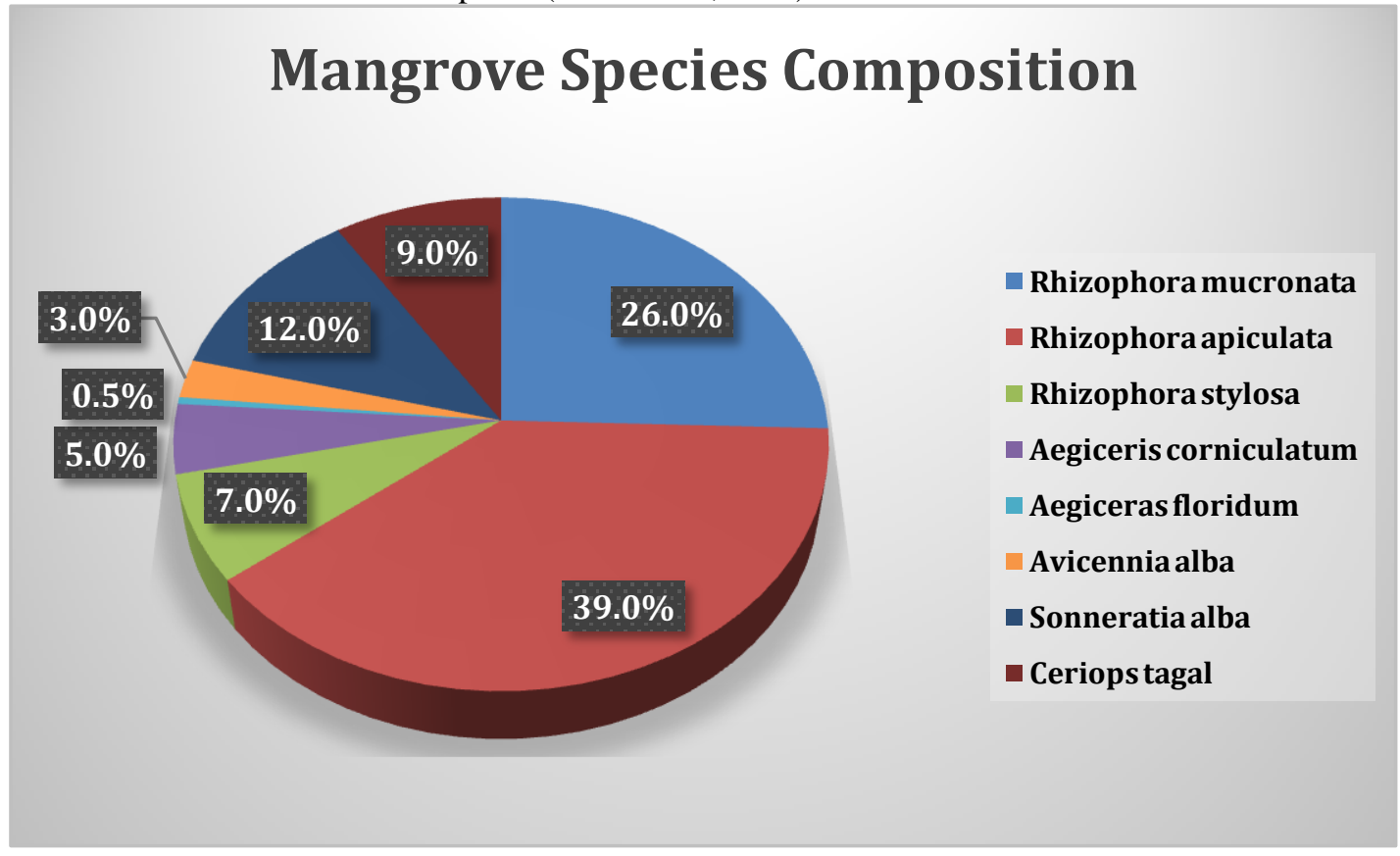

The most abundant species (39.0\%) among eight species in the area is Rhizophora apiculata, followed by Figure 1. Mangrove Species Composition in Tagpait, Aborlan (n=1600 sq.m)

Rhizophora mucronata (26.0\%), Sonneratia alba (12.0\%), Ceriopstagal (9.0\%), and Rhizophora stylosa(7.0\%). The area was planted mostly with trees of the genus Rhizophora (local name: Bakauan). Other species are Aegicerascorniculatum (5.0\%), Avicennia alba (3.0\%), and Aegicerasfloridum (0.5\%). The biodiversity in the area provides benefits to the local community and an indicator of sustainable forest management (Appanah\& Ratman, 1992). 


\section{DOI: $10.51386 / 25815946 / i j s m s-v 4 i 4 p 103$}

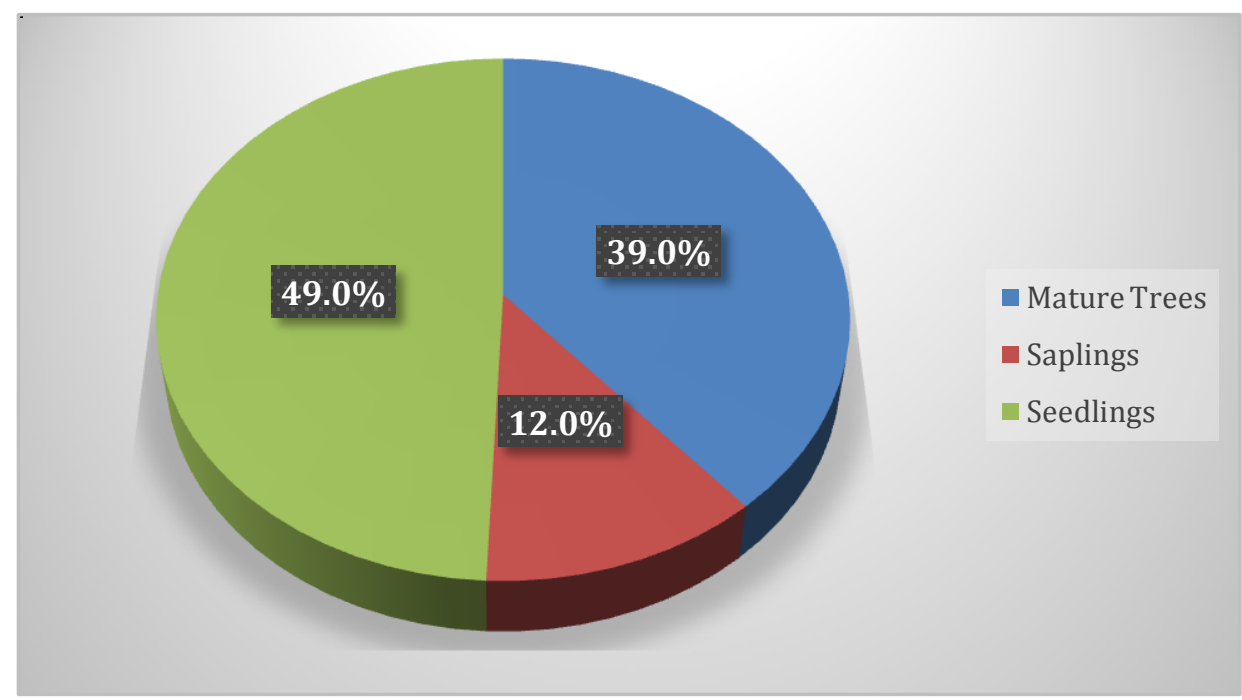

Figure 2. Composition of Mature Trees, Saplings and Seedlings (n=1600 sq.m)

The mangrove forest in Tagpait, Aborlan is composed of mature trees (trunk diameter $>4 \mathrm{~cm}$ and height of tree $>1 \mathrm{~m}$ ), saplings (trunk diameter $=4$ and height of tree $>1 \mathrm{~m}$ ), and seedlings (trunk diameter $<4 \mathrm{~cm}$ and height of tree $\leq 1 \mathrm{~m}$ ). The composition of mature trees, saplings, and seedlings, which is $49.0 \%, 39.0 \%$, and $12.0 \%$, respectively, as presented in Figure 3.

\section{Bacungan}

Bacungan, Puerto Princesa has 378-hectare of mangrove composed of 13 species, as presented in Figure 14. Mangrove species composition and relative abundance were assessed using four transects with a total of 16 quadrats. The area mostly contains the genus of Rhizophora. The average height of trees is 20 meters, and the average diameter at breast height $(\mathrm{DBH})$ is 5 inches $(12.7 \mathrm{~cm})$. The $\mathrm{pH}$ level of soil in Bacungan is 5.46, which is quite acidic. Nitrogen $(\mathrm{N})$, Phosphorus $(\mathrm{P})$, and Potassium $(\mathrm{K})$ is $4.5 \% \mathrm{OM}, 148 \mathrm{ppm}$, and 1,152 ppm, respectively. The percentage of soil organic carbon stock for $100 \mathrm{~g}$ is $1.8 \%$ (1.8 grams), while the percentage of organic matter is $3.096 \%(3.1 \mathrm{~g})$.

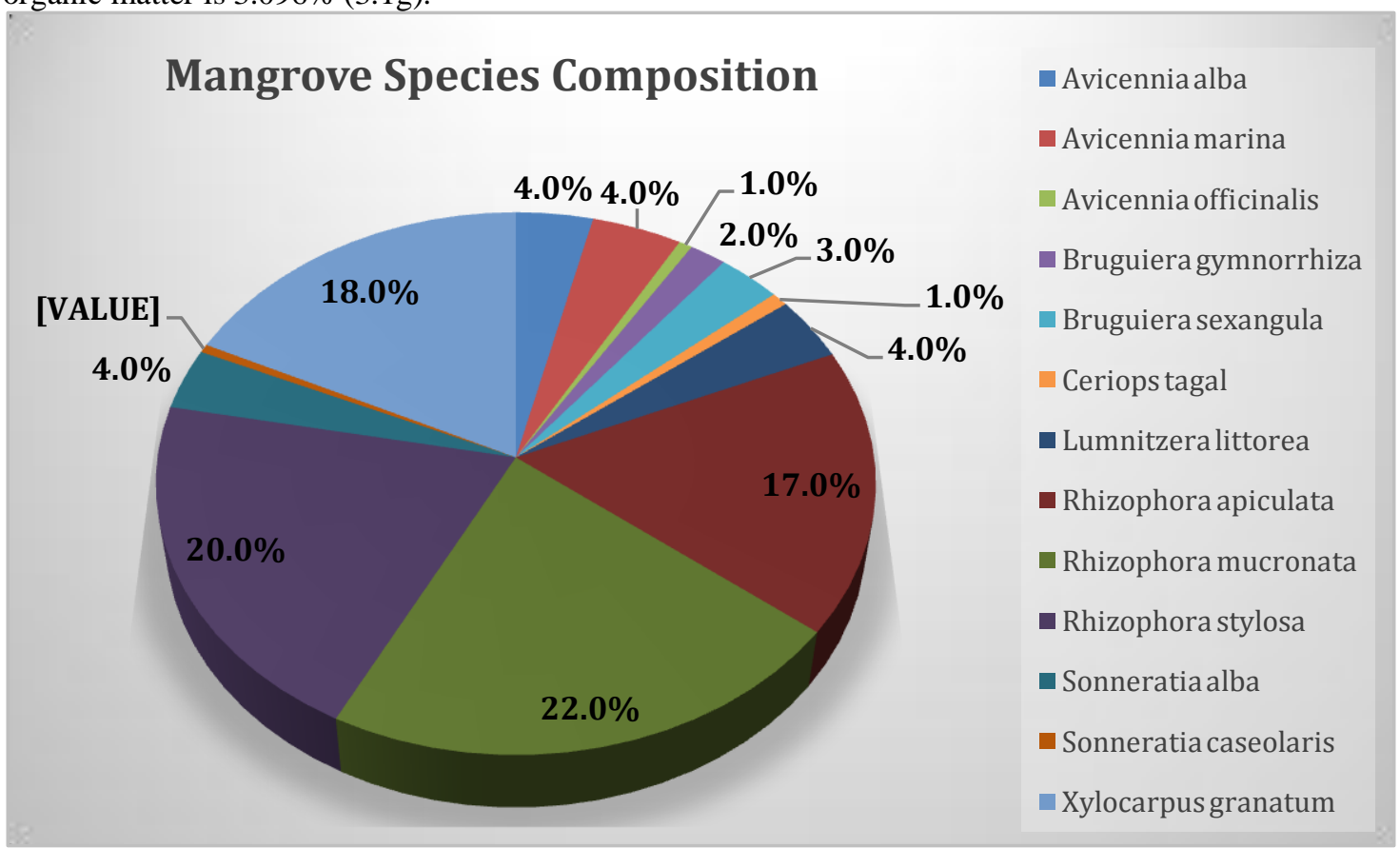

Figure 3. Mangrove Species Composition in Bacungan(n=1600 sq.m) 


\section{DOI: $10.51386 / 25815946 / i j s m s-v 4 i 4 p 103$}

Volume: 4 Issue: 4

Mangrove species composition and relative abundance in Bacungan was stated in Figure 4. The most abundant species (22.0\%) among 13 species in the area is Rhizophora mucronata, followed by Rhizophora stylosa (20.0\%), Xylocarpusgranatum (18.0\%), Rhizophora apiculata $(17.0 \%)$. The area is mostly composed of genus Rhizophora (local name: Bakauan). Other species are Avicennia alba (4.0\%), Avicennia marina (4.0\%), Sonneratia alba (4.0\%), Lumnitzeralittorea (4.0\%), Bruguierasexangula (3.0\%), Bruguieragymnorrhiza (2.0\%), Ceriopstagal (0.8\%), Avicennia officinalis (0.7\%), and Sonneratiacaseolaris (0.5\%).

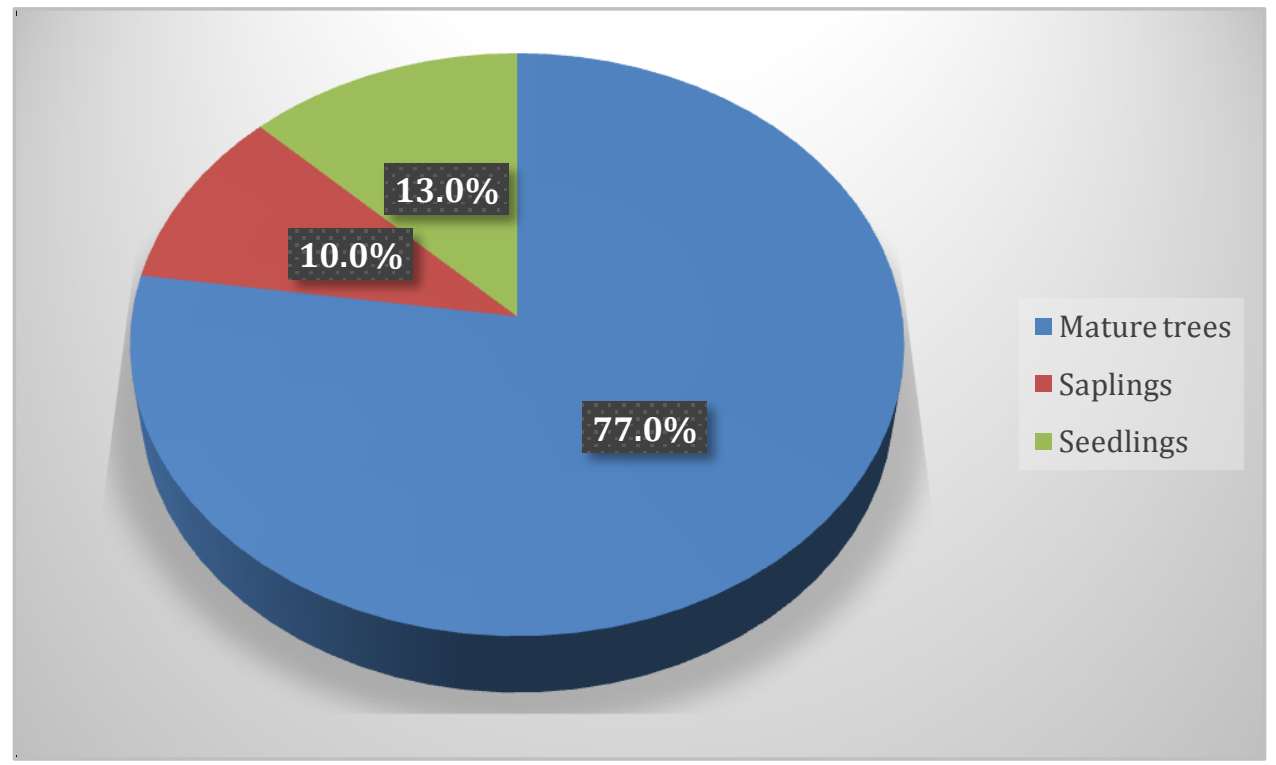

Figure 4. Composition of Mature Trees, Saplings and Seedlings (n=1600 sq.m)

The mangrove forest in Tagpait, Aborlan is composed of mature trees (trunk diameter $>4 \mathrm{~cm}$ and height of tree $>1 \mathrm{~m}$ ), saplings (trunk diameter $=4$ and height of tree $>1 \mathrm{~m}$ ), and seedlings (trunk diameter $<4 \mathrm{~cm}$ and height of tree $\leq 1 \mathrm{~m}$ ). The composition of mature trees, saplings, and seedlings are presented in Figure 5. Seventyseven percent are mature trees, $13.0 \%$ are seedlings, and $10.0 \%$ are saplings.

\section{B. Socio-economic Profile of the Respondents}

1. Age

Figure 6 shows the age distribution (\%) of the respondents in two communities. In Tagpait (n=65), 44.6\% or 29 respondents out of 65 belong to above 60 years old. The organization's initiative for mangrove afforestation started in 1991 in which the majority of its members are already above 60 years old. Then, this was followed by the age group from 41-60 years old, which comprises the $27.7 \%$ (18 respondents out of 65). Next, $21.54 \%$ (14 respondents out of 65) belongs to 51-60 years old. Lastly, 6.15\% or four respondents belong to 30-40 years old. In Bacungan ( $n=30), 36.7 \%$ (11 out of 30 respondents) belong to 30-40 years old. The initiative in the management of mangrove was primarily by the effort of younger ages in the community. Then, this was followed by the age group from above 60 years old, which is $30.0 \%$ ( 9 out of 30 respondents). 23.3\% are between 51-60 (7 respondents out of 30 ). 10.0\% or three respondents belong to 41-50 years old. 


\section{DOI: $10.51386 / 25815946 / i j s m s-v 4 i 4 p 103$}

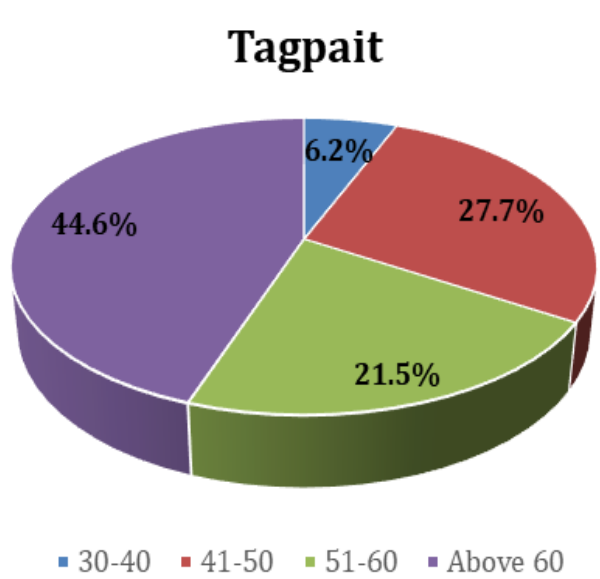

\section{Bacungan}

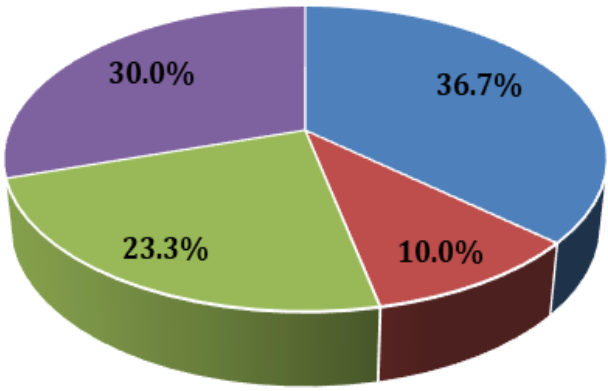

- 30-40 - 41-50 - 51-60 - Above 60

Figure 6. Respondents' Age in years

\section{Gender}

Figure 7 shows the gender of the respondents in two communities. In Tagpait $(n=65)$, the majority are female, which is $62.0 \%$ or 40 respondents out of 65 , while the male comprises $38.0 \%$ (25 respondents out of 65 ). In Bacungan $(n=30), 63.0 \%$ or 19 respondents out of 30 are female while $37.0 \%$ or 11 respondents out of 30 are males.
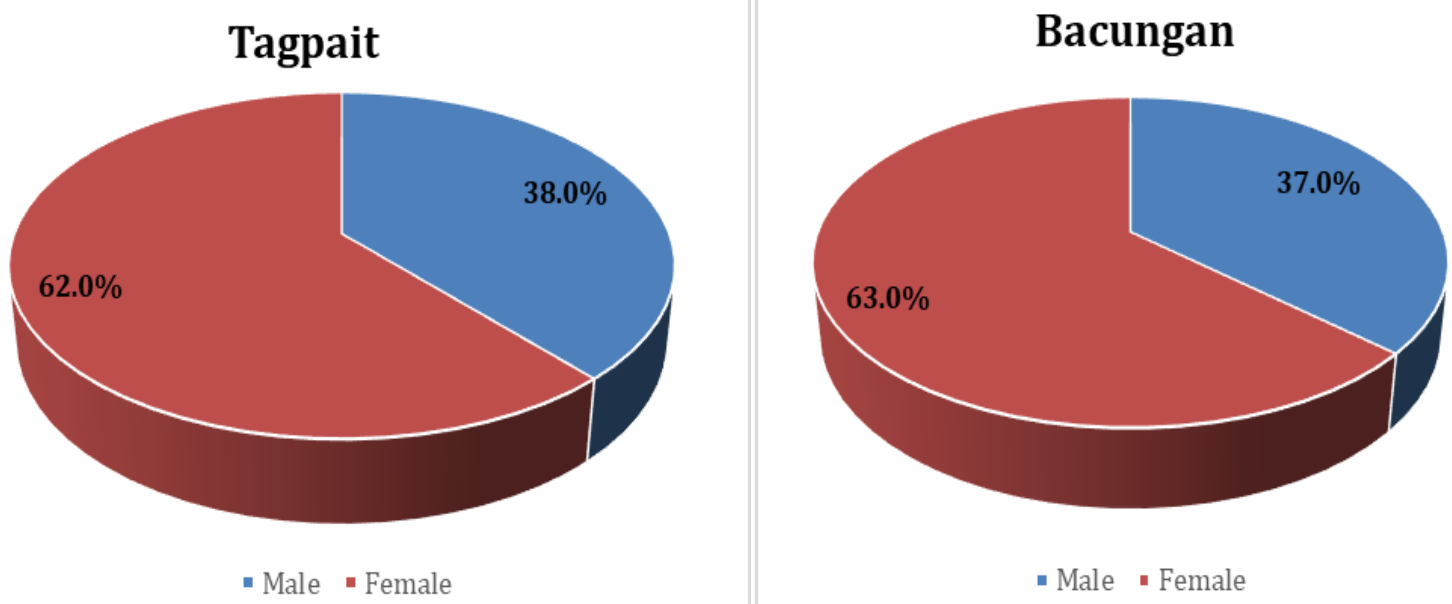

Figure 7. Respondents' Gender

\section{Civil Status}

Figure 8 shows the civil status of the respondents in two communities. In Tagpait (=65), $65 \%$ or 42 respondents out of 65 are married, followed by widow, which comprises $25.0 \%$ or 16 respondents, $6.0 \%$ or four respondents are single, and $5.0 \%$ (three respondents) are separated. In Bacungan $(\mathrm{n}=30), 70.0 \%$ or 21 respondents are married, which is the majority. Then, this was followed by separated, which is $23.3 \%$ or seven respondents, and $6.7 \%$ (two respondents out of 30) are single. Married respondents are the majority in both communities. 
Figure 8. Respondents' Civil Status

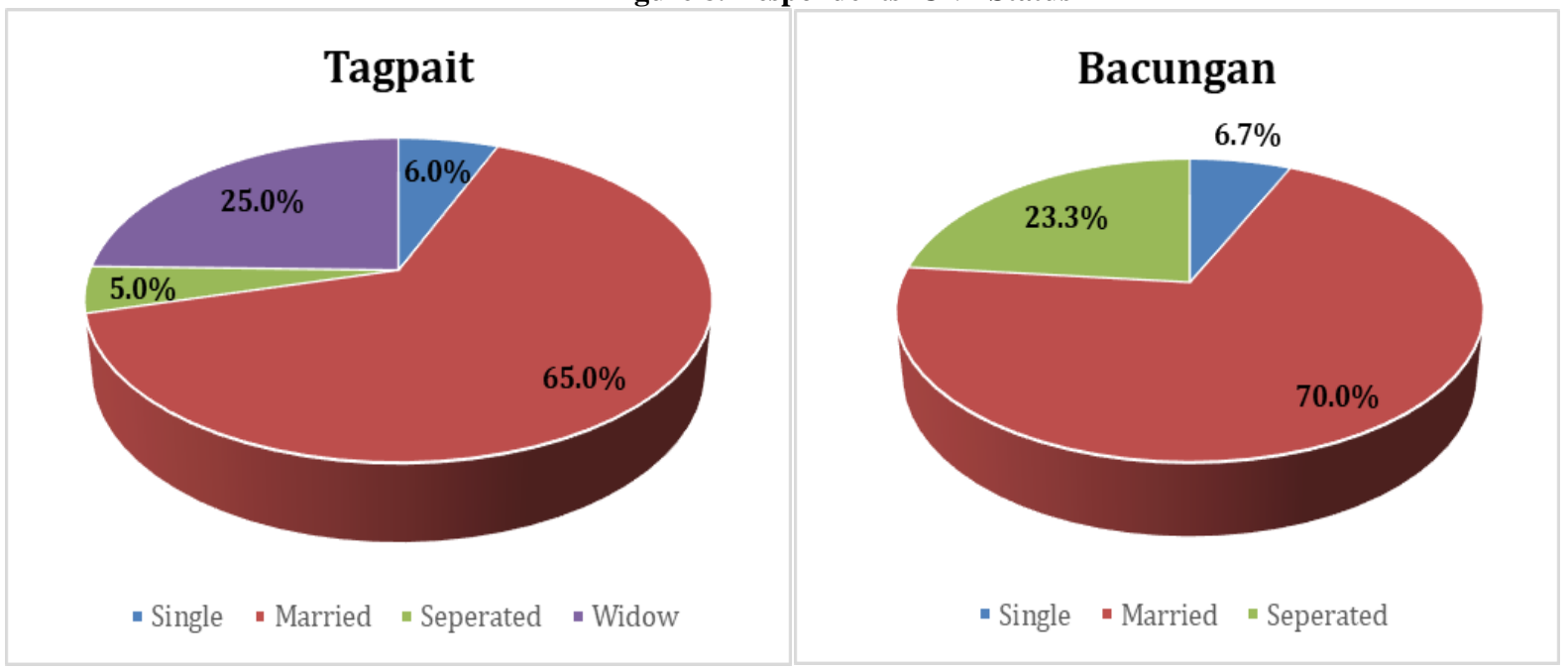

\section{Educational Attainment}

The educational attainment in Tagpait $(n=65)$ is shown in Figure 9. The majority are high school level, which is $33.8 \%$ or 22 respondents, followed by high school graduates $(21.5 \%)$ and elementary graduates $(18.5 \%)$, and only $9.2 \%$ (six out of 65) are elementary level. Both college-level and college graduates comprise 6.2\% (four respondents). In Bacungan $(\mathrm{n}=30)$, the majority are high school level, which is $63.3 \%$ or 19 respondents, followed by elementary graduates $(13.33 \%$ or four respondents), elementary level, vocational and college graduates comprise the $6.7 \%$ or two respondents. Only $3.3 \%$ or one respondent is a high school level. High school graduate is the majority, followed by the elementary graduate in both communities.

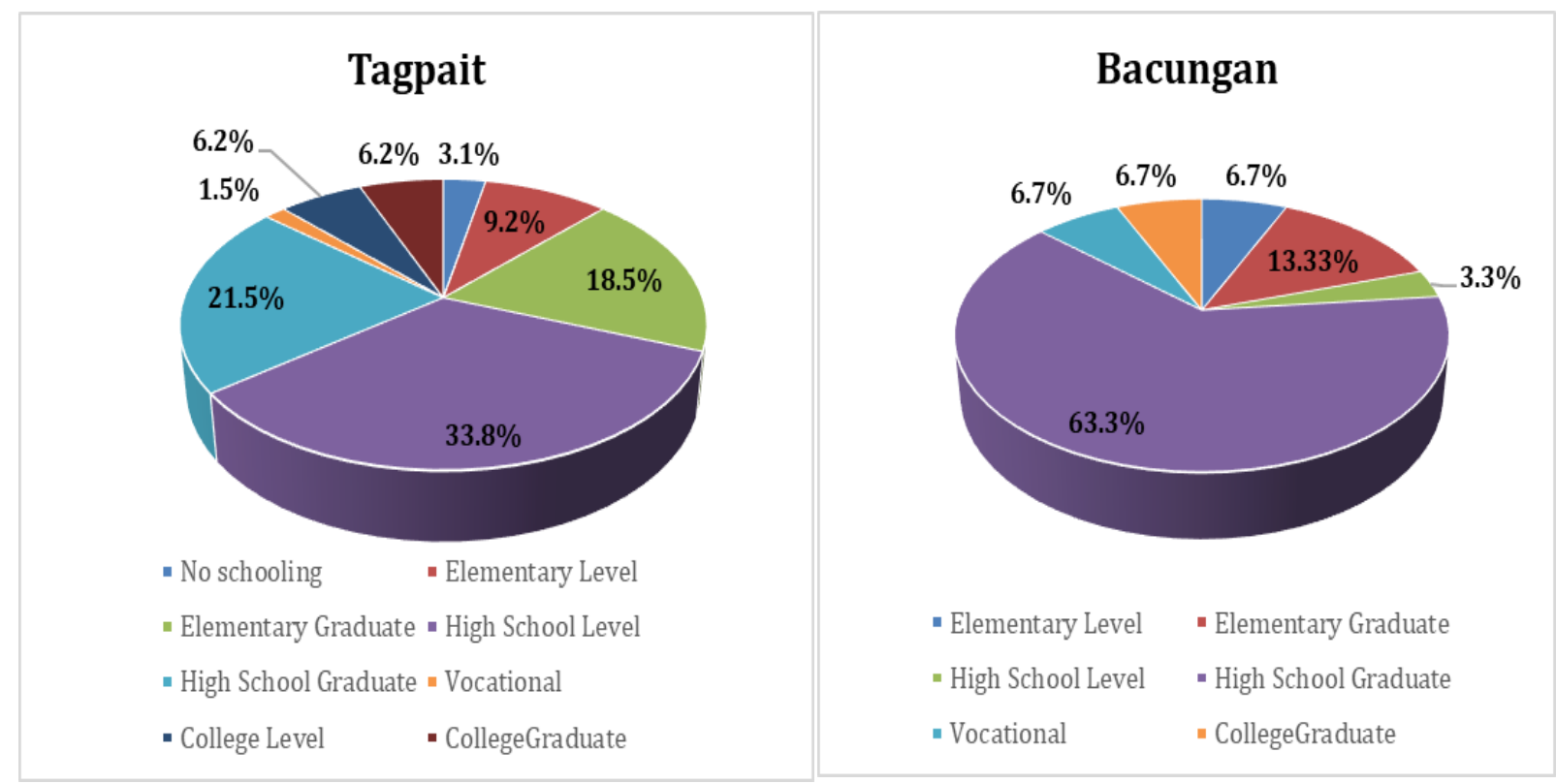

Figure 9. Respondents' Educational Attainment

\section{Livelihood}

Figure 10 shows the respondents' primary livelihood in the two communities. In Tagpait ( $n=65)$, the primary livelihood of the majority is fishing $(20.0 \%$ or 13 respondents), followed by local government employment at $18.0 \%$ or 12 respondents and buying and selling marine products and farming at $14.0 \%$ or nine respondents, and 


\section{DOI: $10.51386 / 25815946 / i j s m s-v 4 i 4 p 103$}

Volume: 4 Issue: 4

self-employed at 12.0\% (8 respondents out of 65). Self-employed are engaged in small businesses like a store. In Bacungan $(n=30)$, the primary livelihood of the majority is fishing at 37.0\% (11 respondents out of 30), buying and selling marine products, farming and self-employment is the second primary livelihood at $13.0 \%$ or four respondents and government employment and laborer at 7.0\% (two respondents out of 30). In both communities, fishing is the top primary livelihood.

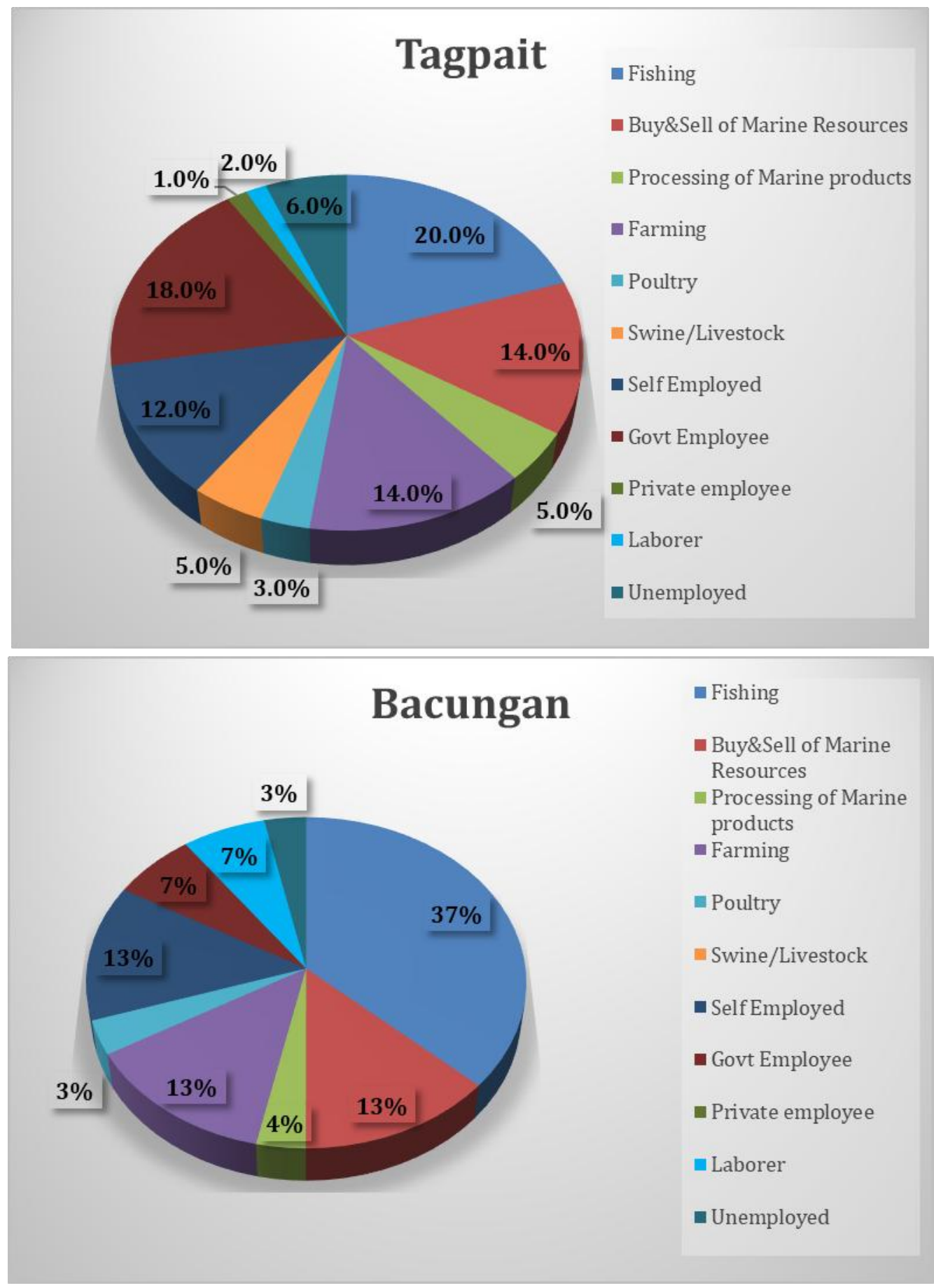

Figure 10. Respondents' Livelihood 


\section{DOI: $10.51386 / 25815946 / i j s m s-v 4 i 4 p 103$}

Volume: 4 Issue: 4

\section{Household Monthly Income (Php)}

Figure 11 shows the respondents' average household monthly income (Php) in the two communities. In Tagpait $(n=65), 75.0 \%$ or 49 respondents have an average household monthly income of Php 5,000 and below, and 18\% or 12 respondents have Php 5,001-10,000. In Bacungan $(n=30), 53.3 \%$ or 16 respondents have an average

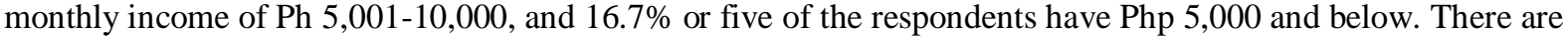
$13.3 \%$ or four respondents of Php 10,001-15,000 per month. The average household monthly income of the majority in Tagpait is Php 5,000 and below, while $\mathrm{Ph}$ 5,001-10,000 in Bacungan.

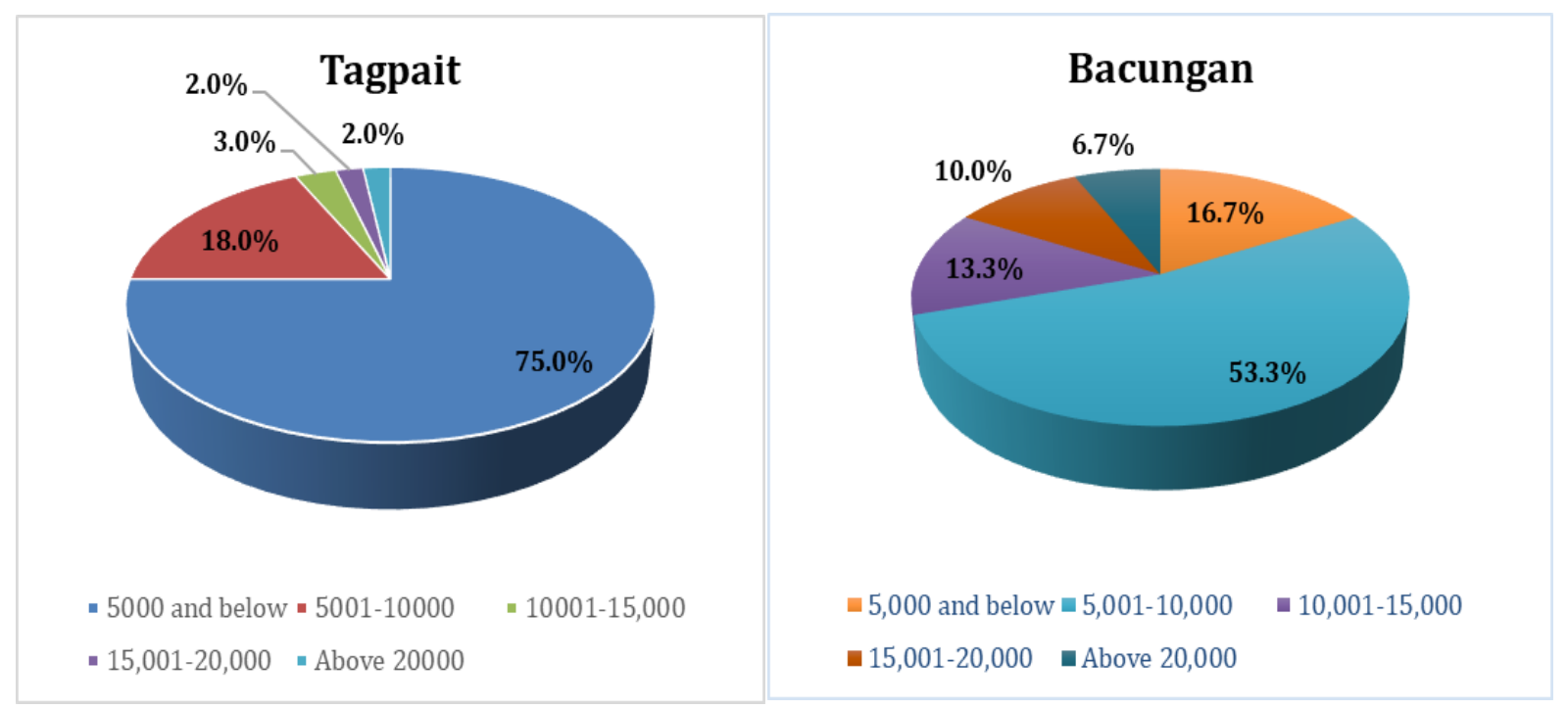

\section{Number of years living in the community}

Figure 12 shows the number of years that the respondents live in the community. In Tagpait, about $45.0 \%$ or 29 respondents have been living in the area for more than 60 years and above. Then, followed by 41-50 years old at $28.0 \%$ or 18 respondents, while those living in the community for 51-60 years and 31-40 years comprise $15.0 \%$ and $11.0 \%$, respectively. In Bacungan, $43.3 \%$ (13 respondents) have been living in the community for 31-40 years. Then, $20.0 \%$ (six respondents out of 30) have been living in the area for 30 years and below. Lastly, respondents who have been living for more than 60 years are $10 \%$ (three respondents).
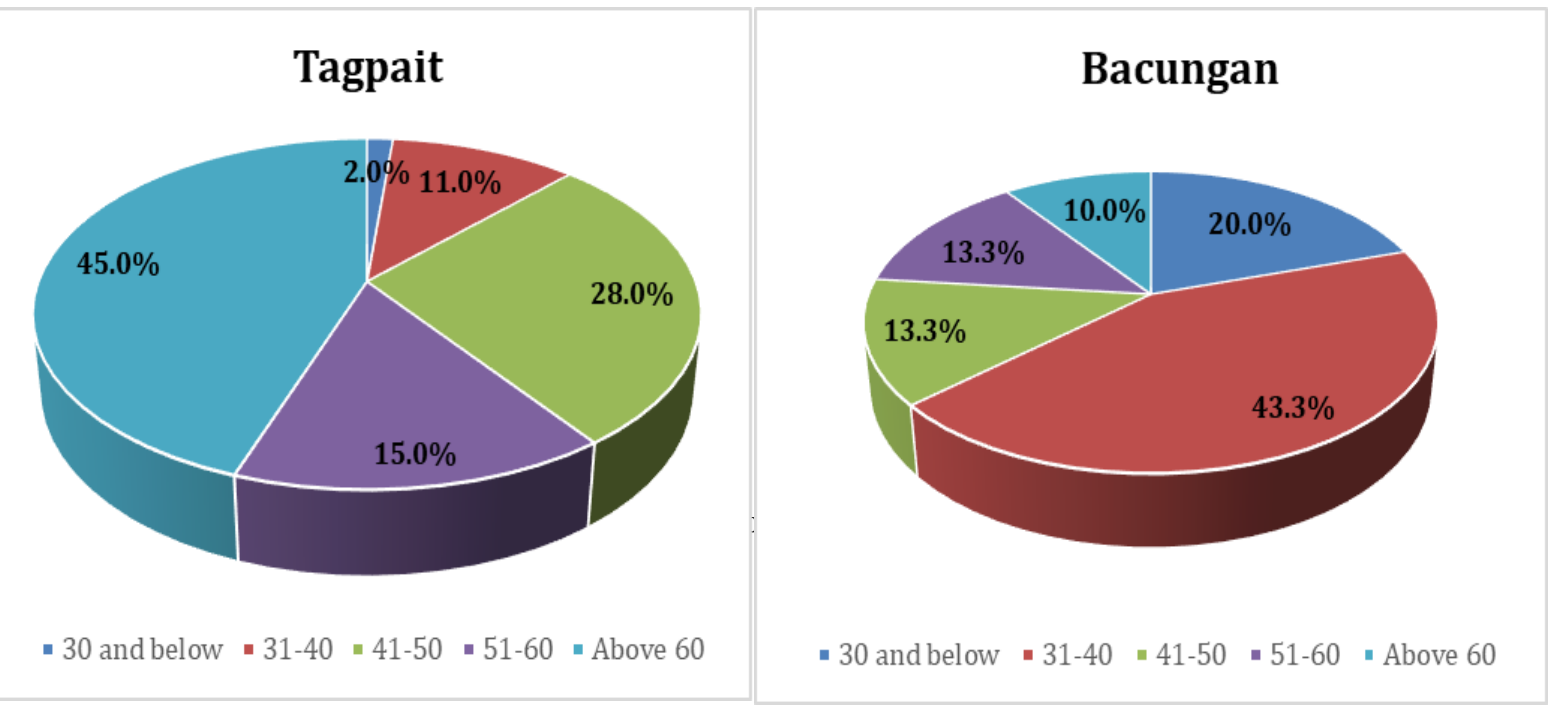

Figure 12.Number of years living in the community 
DOI: $10.51386 / 25815946 / i j s m s-v 4 i 4 p 103$

Volume: 4 Issue: 4

July to August 2021

https://www.ijjsmsjournal.org

\section{CONCLUSION}

- Bacungan is more diverse, with a higher number of species present in the area with 13 species while eight in Tagpait. The most dominant mangrove species in Tagpait is Rhizophora apiculata (39\%), while Rhizophora mucronata in Bacungan (22\%).

- Most of the respondents in Tagpait are fishers, which about 20\%, then $14 \%$ are involved in buy and sell of marine products, and 5\% are engaged in the processing of marine products. In Bacungan, the majority are engaged in fishing livelihood $(37 \%)$, the $13 \%$ are involved in buy and sell of marine products, and $4 \%$ are engaged in the processing of marine products.

\section{RECOMMENDATIONS}

Based on the results of the study, the researchers make the following recommendations:

- Regular monitoring of the mangrove biophysical condition

- Planting mangroves in vacant spaces inside the mangrove area

- The government and non-government agencies may provide financial and technical support to improve the livelihood of the community as managers of mangrove.

\section{REFERENCES}

[1] Appanah, S., \& Ratnam, L. (1992). The Importance of Forest Biodiversity to Developing Countries in Asia. Journal of Tropical Forest Science, 5(2), 201-215. Retrieved from www.jstor.org/stable/43581027.

[2] Buncag, M.J., \&Lubrico, Y. (2016). Use Value of Afforested Mangrove in Tagpait, Aborlan. Palawan State University Research Journal, 9 (1), 16-30.

[3] Datta, D., Chattopadhyay, R. N., \& Guha, P. (2012). Community Based Mangrove Assessment: A Review on Status and Sustainability. Journal of Environmental Management. 107 (30), pp 84-95, Retrieved at https://doi.org/10.1016/j.jenvman.2012.04.013.

[4] Dela Peña, H. P., Flores, C. G., Buncag, M.J. J., Lubrico, L. Y. \&Pacañot, E. B. (2013). Ecotourism in community-based mangrove afforestation in Tagpait, Aborlan, Palawan. BIMP-EAGA Journal for Sustainable Tourism Development, 2(2), 47-50.

[5] Khanom, S., Shah, M. A. R., \& Chaudhary, A. (2011). Towards Ecotourism: Issue of Current Tourism Practices in the Sundarban Mangrove Forest, Bangladesh. Retrieved at https://www.researchgate.net/publication/281585584_Towards_ecotourism_issues_of_current_tourism_practices_in_the_Sundarban_ mangrove_forest_Bangladesh.

[6] Lasco, R., MacDicken, G., Pulhin, F., Guillermo, I., Sales, R., \& Cruz, R. (2006). Carbon Stocks Assessment of a Selectively Logged Dipterocarp Forest and Wood Processing Mill in the Philippines. Journal of Tropical Forest Science, 18(4), 212-221. Retrieved from www.jstor.org/stable/43594677.

[7] Participatory Coastal Resource Assessment (2013). The coastal and marine ecosystems: An overview. Participatory Coastal Resource Assessment Lecture. Retrieved athttp://oneocean.org/download/db_files/PCRA_lectures.pdf.

[8] Pokharel, R. K., Neupane, P., Tiwari, K., \& Kohl, M. (2014). Assessing Sustainability in Community Based Forestry: A Case from Nepal. Forest Policy and Economics Journal, Elsevier, 12 (09), 1-11. DOI: 10.1016/j.forpol.2014.11.006.

[9] Rahman, M. M., Rahman, M. M., \& Islam, K. M. (2010). The Causes of Deterioration of Sundarban Mangrove Forest Ecosystem of Bangladesh: Conservation and Sustainable Management Issues. Aquaculture, Aquarium, Conservation, and Legislation International Journal of the Bioflux Society, 2 (3), 77-90.

[10] Regoniel, P. A., \&Pacañot, E. B. (2012). Family-based mangrove afforestation in Tagpait, Aborlan, Palawan: Sustaining the Drive Toward Sustainable Development. Palawan State University Journal, 2013, 5(1), 8-13. 